Appendices DR1-DR4 Zwahlen et al., 2017, Estimating carbon dioxide emplacement timescales through noble gas and stable isotope diffusion profiles

\title{
Appendix DR1 (Table DR1)
}

Table DR1. Noble gas concentrations, carbon and oxygen stable isotopes and distance to the gas water contact of the 26 Bravo Dome samples with errors and corrected noble gas concentrations. 


\begin{tabular}{|c|c|c|c|c|c|c|c|c|c|c|c|c|c|c|}
\hline Sample id & $\begin{array}{l}\delta^{13} \mathrm{C} \\
{[\%]}\end{array}$ & $\begin{array}{c}\delta^{13} \mathrm{C} \text { Error } \\
{[1 \sigma]}\end{array}$ & $\begin{array}{l}\delta^{18} \mathrm{O} \\
{[\%]}\end{array}$ & $\begin{array}{c}8^{18} \mathrm{O} \text { Error } \\
{[1 \sigma]}\end{array}$ & $\begin{array}{c}\text { Distance to } \\
\text { groundwater } \\
{[\mathrm{km}]} \\
\end{array}$ & $\begin{array}{c}\text { Error range on } \\
\text { distance to groundwater } \\
{[\mathrm{km}]} \\
\end{array}$ & $\begin{array}{c}{ }^{3} \mathrm{He} \\
{\left[\mathrm{cm}^{3} \mathrm{STP}\right.} \\
\left.\mathrm{cm}^{-3}\right] \\
\end{array}$ & ${ }^{3} \mathrm{He}$ Error & $\begin{array}{c}{ }^{4} \mathrm{He} \\
{\left[\mathrm{cm}^{3} \mathrm{STP}\right.} \\
\left.\mathrm{cm}^{-3}\right]\end{array}$ & $\begin{array}{c}{ }^{4} \mathrm{He} \text { Error } \\
{[1 \sigma]}\end{array}$ & $\begin{array}{c}{ }^{4} \mathrm{He} \text { corrected } \\
{\left[\mathrm{cm}^{3} \mathrm{STP}\right.} \\
\left.\mathrm{cm}^{-3}\right] \\
\end{array}$ & $\begin{array}{c}{ }^{20} \mathrm{Ne} \\
{\left[\mathrm{cm}^{3} \mathrm{STP}\right.} \\
\left.\mathrm{cm}^{-3}\right] \\
\end{array}$ & 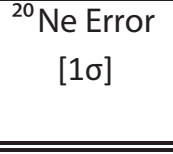 & $\begin{array}{c}{ }^{20} \begin{array}{c}\text { Ne corrected } \\
{\left[\mathrm{cm}^{3} \mathrm{STP}\right.} \\
\left.\mathrm{cm}^{-3}\right]\end{array} \\
\end{array}$ \\
\hline $4 \mathrm{~b}$ & -3.7 & 0.1 & 19.3 & 0.1 & 21.200 & 0.250 & $2.16 \mathrm{E}-10$ & $2.51 \mathrm{E}-11$ & $4.01 \mathrm{E}-05$ & $4.00 \mathrm{E}-06$ & $2.55 \mathrm{E}-05$ & $\begin{array}{l}1.09 E-09 \\
\end{array}$ & $2.59 \mathrm{E}-11$ & $1.09 \mathrm{E}-09$ \\
\hline $12 \mathrm{~b}$ & -3.8 & 0.1 & 22.9 & 0.1 & 18.300 & 0.250 & $2.10 \mathrm{E}-10$ & $3.58 \mathrm{E}-12$ & $4.13 \mathrm{E}-05$ & $5.00 \mathrm{E}-07$ & $2.77 E-05$ & $1.20 \mathrm{E}-09$ & $1.50 \mathrm{E}-11$ & $1.23 \mathrm{E}-09$ \\
\hline $12 \mathrm{~b}(2)$ & -3.8 & 0.1 & 22.7 & 0.1 & 18.300 & 0.250 & 2.10E-10 & $3.58 \mathrm{E}-12$ & $4.13 \mathrm{E}-05$ & $5.00 \mathrm{E}-07$ & $2.77 E-05$ & $1.20 \mathrm{E}-09$ & $1.50 \mathrm{E}-11$ & $1.23 \mathrm{E}-09$ \\
\hline $15 b$ & -4.0 & 0.1 & 28.9 & 0.1 & 2.000 & 0.250 & $1.98 \mathrm{E}-10$ & 1.47E-11 & $5.83 \mathrm{E}-05$ & $3.30 \mathrm{E}-06$ & $4.70 \mathrm{E}-05$ & $1.70 \mathrm{E}-09$ & 4.03E-11 & $1.79 \mathrm{E}-09$ \\
\hline $13 b$ & -4.3 & 0.1 & 30.3 & 0.1 & 0.700 & 0.250 & $2.75 \mathrm{E}-10$ & $1.76 \mathrm{E}-11$ & $1.54 \mathrm{E}-04$ & $1.90 \mathrm{E}-06$ & $1.28 \mathrm{E}-04$ & 2.97E-09 & $7.04 \mathrm{E}-11$ & $2.67 \mathrm{E}-09$ \\
\hline $13 b(2)$ & -4.3 & 0.1 & 30.1 & 0.1 & 0.700 & 0.250 & $2.75 \mathrm{E}-10$ & $1.76 \mathrm{E}-11$ & $1.54 \mathrm{E}-04$ & $1.90 \mathrm{E}-06$ & $1.28 \mathrm{E}-04$ & $2.97 \mathrm{E}-09$ & $7.04 \mathrm{E}-11$ & $2.67 \mathrm{E}-09$ \\
\hline $7 \mathrm{~b}(2)$ & -5.4 & 0.1 & 30.0 & 0.1 & 0.071 & 0.020 & $2.41 \mathrm{E}-10$ & $1.08 \mathrm{E}-11$ & $8.22 \mathrm{E}-05$ & $9.50 \mathrm{E}-07$ & $6.28 \mathrm{E}-05$ & $1.93 \mathrm{E}-09$ & 4.64E-11 & $1.80 \mathrm{E}-09$ \\
\hline $7 \mathrm{~b}$ & -5.4 & 0.1 & 29.9 & 0.1 & 0.071 & 0.020 & $2.41 \mathrm{E}-10$ & $1.08 \mathrm{E}-11$ & $8.22 \mathrm{E}-05$ & $9.50 \mathrm{E}-07$ & $6.28 \mathrm{E}-05$ & $1.93 \mathrm{E}-09$ & 4.64E-11 & $1.80 \mathrm{E}-09$ \\
\hline $5 b$ & -5.1 & 0.1 & 30.2 & 0.1 & 0.033 & 0.018 & $3.47 \mathrm{E}-10$ & 7.76E-12 & $2.80 \mathrm{E}-04$ & $1.20 \mathrm{E}-06$ & $2.41 \mathrm{E}-04$ & $5.08 \mathrm{E}-09$ & $1.20 \mathrm{E}-10$ & 4.42E-09 \\
\hline W1b & -3.7 & 0.1 & 18.6 & 0.1 & 23.600 & 0.250 & $2.46 \mathrm{E}-10$ & $6.84 \mathrm{E}-12$ & $5.58 \mathrm{E}-05$ & $4.70 \mathrm{E}-07$ & $3.54 \mathrm{E}-05$ & $1.44 \mathrm{E}-09$ & $3.43 \mathrm{E}-11$ & $1.28 \mathrm{E}-09$ \\
\hline W3b & -3.8 & 0.1 & 19.8 & 0.1 & 23.600 & 0.250 & $2.35 \mathrm{E}-10$ & $8.37 \mathrm{E}-12$ & $6.64 \mathrm{E}-05$ & $5.00 \mathrm{E}-07$ & $4.81 \mathrm{E}-05$ & $1.60 \mathrm{E}-09$ & $3.80 \mathrm{E}-11$ & $1.50 \mathrm{E}-09$ \\
\hline $11 \mathrm{~b}$ & -3.4 & 0.1 & 21.0 & 0.1 & 15.900 & 0.250 & 2.03E-10 & $8.91 \mathrm{E}-12$ & $3.93 E-05$ & $1.10 \mathrm{E}-06$ & $2.71 \mathrm{E}-05$ & $1.20 \mathrm{E}-09$ & $2.89 \mathrm{E}-11$ & $1.27 \mathrm{E}-09$ \\
\hline $20 \mathrm{~b}$ & -3.8 & 0.1 & 18.9 & 0.1 & 16.800 & 0.250 & 2.17E-10 & 3.00E-11 & 4.17E-05 & $5.00 \mathrm{E}-06$ & $2.68 \mathrm{E}-05$ & $1.21 \mathrm{E}-09$ & $2.92 \mathrm{E}-11$ & $1.20 \mathrm{E}-09$ \\
\hline $4 \mathrm{~b}$ & -4.9 & 0.1 & 28.0 & 0.1 & 0.068 & 0.025 & $2.08 \mathrm{E}-10$ & $8.94 \mathrm{E}-12$ & $9.84 \mathrm{E}-05$ & $2.40 \mathrm{E}-06$ & $8.51 \mathrm{E}-05$ & $2.35 \mathrm{E}-09$ & $5.65 \mathrm{E}-11$ & $2.39 \mathrm{E}-09$ \\
\hline $2 b$ & -5.8 & 0.1 & 29.0 & 0.1 & 0.021 & 0.017 & $4.75 \mathrm{E}-10$ & $4.28 \mathrm{E}-11$ & $4.77 \mathrm{E}-04$ & $1.40 \mathrm{E}-06$ & $4.13 \mathrm{E}-04$ & $9.43 \mathrm{E}-09$ & $2.23 \mathrm{E}-11$ & $8.12 \mathrm{E}-09$ \\
\hline $4 c$ & -3.7 & 0.1 & & & 25.000 & 0.250 & 1.57E-10 & $6.21 \mathrm{E}-12$ & $2.85 \mathrm{E}-05$ & $3.10 \mathrm{E}-07$ & 2.50E-05 & & & \\
\hline $2 c$ & -3.7 & 0.1 & & & 27.800 & 0.250 & & & & & & & & \\
\hline $8 c$ & -3.7 & 0.1 & & & 26.000 & 0.250 & $1.38 \mathrm{E}-10$ & $5.79 \mathrm{E}-12$ & $2.60 \mathrm{E}-05$ & $2.84 \mathrm{E}-07$ & $2.60 \mathrm{E}-05$ & & & \\
\hline $11 \mathrm{c}$ & -3.7 & 0.1 & & & 21.200 & 0.250 & $1.35 \mathrm{E}-10$ & $5.09 \mathrm{E}-12$ & $2.94 \mathrm{E}-05$ & $3.16 \mathrm{E}-07$ & $3.00 \mathrm{E}-05$ & & & \\
\hline $15 c$ & -3.9 & 0.1 & & & 29.800 & 0.250 & $1.43 \mathrm{E}-10$ & $5.79 \mathrm{E}-12$ & $3.04 \mathrm{E}-05$ & $3.31 \mathrm{E}-07$ & $2.95 \mathrm{E}-05$ & & & \\
\hline 9c & -3.2 & 0.1 & & & 21.200 & 0.250 & & & & & & & & \\
\hline $13 c$ & -4.1 & 0.1 & & & 28.400 & 0.250 & & & & & & & & \\
\hline 6c & -3.9 & 0.1 & & & 28.800 & 0.250 & & & & & & & & \\
\hline $12 c$ & -4.0 & 0.1 & & & 24.000 & 0.250 & & & & & & & & \\
\hline $14 c$ & -4.0 & 0.1 & & & 27.900 & 0.250 & & & & & & & & \\
\hline $10 c$ & -3.8 & 0.1 & & & 21.200 & 0.250 & $1.95 \mathrm{E}-10$ & $7.22 \mathrm{E}-12$ & $2.97 E-05$ & 3.19E-07 & $1.89 \mathrm{E}-05$ & & & \\
\hline $7 c$ & -4.2 & 0.1 & & & 30.800 & 0.250 & $1.91 \mathrm{E}-10$ & $7.16 \mathrm{E}-12$ & $9.83 \mathrm{E}-05$ & $1.06 \mathrm{E}-06$ & $8.83 \mathrm{E}-05$ & & & \\
\hline $3 c$ & -3.8 & 0.1 & & & 28.400 & 0.250 & & & & & & & & \\
\hline $5 c$ & -4.0 & 0.1 & & & 27.800 & 0.250 & $1.49 \mathrm{E}-10$ & $6.04 \mathrm{E}-12$ & $2.87 \mathrm{E}-05$ & 3.12E-07 & 2.66E-05 & & & \\
\hline Sample id & $\begin{array}{c}{ }^{36} \mathrm{Ar} \\
{\left[\mathrm{cm}^{3} \mathrm{STP}\right.} \\
\left.\mathrm{cm}^{-3}\right] \\
\end{array}$ & $\begin{array}{c}{ }^{36} \mathrm{Ar} \text { Errror } \\
{[1 \sigma]}\end{array}$ & $\begin{array}{c}{ }^{36} \mathrm{Ar} \text { corrected } \\
{\left[\mathrm{cm}^{3} \mathrm{STP}\right.} \\
\left.\mathrm{cm}^{-3}\right] \\
\end{array}$ & $\begin{array}{c}{ }^{40} \mathrm{Ar} \\
{\left[\mathrm{cm}^{3} \mathrm{STP}\right.} \\
\left.\mathrm{cm}^{-3}\right] \\
\end{array}$ & $\begin{array}{l}{ }^{40} \mathrm{Ar} \text { Error } \\
\text { [1]] }\end{array}$ & $\begin{array}{c}{ }^{40} \mathrm{Ar} \text { corrected } \\
{\left[\mathrm{cm}^{3} \mathrm{STP}\right.} \\
\left.\mathrm{cm}^{-3}\right] \\
\end{array}$ & $\begin{array}{c}{ }^{84} \mathrm{Kr} \\
{\left[\mathrm{cm}^{3} \mathrm{STP}\right.} \\
\left.\mathrm{cm}^{-3}\right] \\
\end{array}$ & $\begin{array}{c}{ }^{84} \mathrm{Kr} \text { Error } \\
1 \sigma\end{array}$ & $\begin{array}{c}{ }^{84} \mathrm{Kr} \text { corrected } \\
{\left[\mathrm{cm}^{3} \mathrm{STP}\right.} \\
\left.\mathrm{cm}^{-3}\right] \\
\end{array}$ & $\begin{array}{c}{ }^{132} \mathrm{Xe} \\
{\left[\mathrm{cm}^{3} \mathrm{STP}\right.} \\
\left.\mathrm{cm}^{-3}\right]\end{array}$ & $\begin{array}{c}{ }^{132} \mathrm{Xe} \text { Error } \\
1 \sigma\end{array}$ & $\begin{array}{c}{ }^{132} \text { Xe corrected } \\
{\left[\mathrm{cm}^{3} \mathrm{STP}\right.} \\
\left.\mathrm{cm}^{-3}\right]\end{array}$ & & \\
\hline "4b & 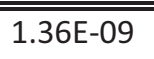 & 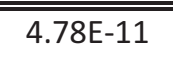 & 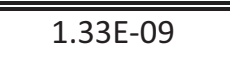 & 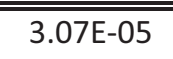 &  & 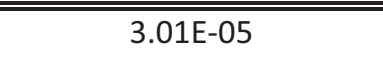 & 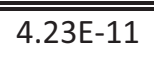 & $\begin{array}{l}2.51 \mathrm{E}-12 \\
\end{array}$ & 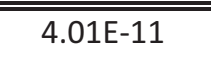 & "6.87E-12 & 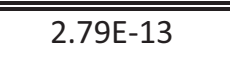 & 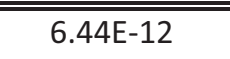 & & \\
\hline $12 b$ & 1.06E-09 & 3.60E-11 & $1.06 \mathrm{E}-09$ & 2.40E-05 & $3.80 \mathrm{E}-07$ & 2.40E-05 & 4.90E-11 & $2.30 \mathrm{E}-12$ & 4.77E-11 & $7.28 \mathrm{E}-12$ & $2.18 \mathrm{E}-13$ & 7.03E-12 & & \\
\hline $12 \mathrm{~b}(2)$ & 1.06E-09 & $3.60 \mathrm{E}-11$ & $1.06 \mathrm{E}-09$ & 2.40E-05 & $3.80 \mathrm{E}-07$ & 2.40E-05 & 4.90E-11 & $2.30 \mathrm{E}-12$ & $4.77 \mathrm{E}-11$ & $7.28 \mathrm{E}-12$ & $2.18 \mathrm{E}-13$ & 7.03E-12 & & \\
\hline $15 \mathrm{~b}$ & $2.31 \mathrm{E}-09$ & $3.88 \mathrm{E}-11$ & $2.37 \mathrm{E}-09$ & $3.11 \mathrm{E}-05$ & 4.21E-07 & $3.25 \mathrm{E}-05$ & $5.14 \mathrm{E}-11$ & $9.73 \mathrm{E}-12$ & $5.22 \mathrm{E}-11$ & $1.04 \mathrm{E}-11$ & $4.41 \mathrm{E}-13$ & $1.06 \mathrm{E}-11$ & & \\
\hline $13 b$ & $5.80 \mathrm{E}-09$ & $1.45 \mathrm{E}-10$ & $5.47 \mathrm{E}-09$ & 4.50E-05 & $6.09 \mathrm{E}-07$ & $3.76 \mathrm{E}-05$ & $1.99 \mathrm{E}-10$ & $4.75 \mathrm{E}-12$ & $1.87 \mathrm{E}-10$ & $2.12 \mathrm{E}-11$ & $8.89 \mathrm{E}-13$ & $1.88 \mathrm{E}-11$ & & \\
\hline $13 \mathrm{~b}(2)$ & $5.80 \mathrm{E}-09$ & $1.45 \mathrm{E}-10$ & $5.47 \mathrm{E}-09$ & $4.50 \mathrm{E}-05$ & $6.09 \mathrm{E}-07$ & $3.76 \mathrm{E}-05$ & $1.99 \mathrm{E}-10$ & $4.75 \mathrm{E}-12$ & $1.87 \mathrm{E}-10$ & $2.12 \mathrm{E}-11$ & $8.89 \mathrm{E}-13$ & $1.88 \mathrm{E}-11$ & & \\
\hline $7 \mathrm{~b}(2)$ & $3.11 \mathrm{E}-09$ & $2.89 \mathrm{E}-11$ & $2.95 \mathrm{E}-09$ & $3.48 \mathrm{E}-05$ & 4.71E-07 & 3.13E-05 & $1.05 \mathrm{E}-10$ & $7.09 \mathrm{E}-12$ & $9.85 \mathrm{E}-11$ & $1.31 \mathrm{E}-11$ & $6.64 \mathrm{E}-13$ & $1.18 \mathrm{E}-11$ & & \\
\hline $7 \mathrm{~b}$ & $3.11 \mathrm{E}-09$ & $2.89 \mathrm{E}-11$ & $2.95 \mathrm{E}-09$ & $3.48 \mathrm{E}-05$ & 4.71E-07 & 3.13E-05 & $1.05 \mathrm{E}-10$ & $7.09 \mathrm{E}-12$ & $9.85 \mathrm{E}-11$ & $1.31 \mathrm{E}-11$ & $6.64 \mathrm{E}-13$ & $1.18 \mathrm{E}-11$ & & \\
\hline $5 b$ & $1.13 \mathrm{E}-08$ & $3.14 \mathrm{E}-11$ & $1.07 \mathrm{E}-08$ & $6.00 \mathrm{E}-05$ & $8.13 \mathrm{E}-07$ & $4.44 \mathrm{E}-05$ & $3.53 \mathrm{E}-11$ & $1.46 \mathrm{E}-11$ & $1.07 E-11$ & 4.10E-11 & $1.70 \mathrm{E}-12$ & $3.62 \mathrm{E}-11$ & & \\
\hline W1b & $1.71 \mathrm{E}-09$ & $4.95 \mathrm{E}-11$ & $1.53 \mathrm{E}-09$ & $3.17 \mathrm{E}-05$ & $4.28 \mathrm{E}-07$ & 2.76E-05 & $5.42 \mathrm{E}-11$ & $4.33 \mathrm{E}-12$ & 4.67E-11 & $8.25 \mathrm{E}-12$ & 3.40E-13 & $6.80 \mathrm{E}-12$ & & \\
\hline W3b & $1.85 \mathrm{E}-09$ & 1.17E-10 & $1.73 \mathrm{E}-09$ & $3.11 \mathrm{E}-05$ & 4.21E-07 & $2.83 E-05$ & $5.52 \mathrm{E}-11$ & $8.36 \mathrm{E}-12$ & 4.97E-11 & $9.22 \mathrm{E}-12$ & $3.39 \mathrm{E}-13$ & $8.15 \mathrm{E}-12$ & & \\
\hline $11 \mathrm{~b}$ & $1.41 \mathrm{E}-09$ & $6.36 \mathrm{E}-11$ & $1.45 \mathrm{E}-09$ & $2.79 \mathrm{E}-05$ & $3.81 \mathrm{E}-07$ & $2.88 \mathrm{E}-05$ & $3.46 \mathrm{E}-11$ & $8.06 \mathrm{E}-12$ & $3.46 \mathrm{E}-11$ & $6.69 \mathrm{E}-12$ & $5.72 \mathrm{E}-13$ & $6.69 \mathrm{E}-12$ & & \\
\hline $20 \mathrm{~b}$ & $1.38 \mathrm{E}-09$ & 6.67E-11 & $1.34 \mathrm{E}-09$ & 2.95E-05 & 4.00E-07 & $2.87 \mathrm{E}-05$ & $3.68 \mathrm{E}-11$ & $5.42 \mathrm{E}-12$ & $3.43 E-11$ & $6.70 \mathrm{E}-12$ & $2.81 \mathrm{E}-13$ & $6.22 \mathrm{E}-12$ & & \\
\hline $4 b$ & $3.44 \mathrm{E}-09$ & $2.32 \mathrm{E}-10$ & $3.45 \mathrm{E}-09$ & $3.31 \mathrm{E}-05$ & $4.48 \mathrm{E}-07$ & 3.33E-05 & 1.10E-10 & $8.32 \mathrm{E}-12$ & $1.09 \mathrm{E}-10$ & 1.40E-11 & $6.05 \mathrm{E}-13$ & $1.38 \mathrm{E}-11$ & & \\
\hline $2 b$ & $1.84 \mathrm{E}-08$ & $3.92 \mathrm{E}-10$ & $1.71 \mathrm{E}-08$ & 7.72E-05 & $1.05 \mathrm{E}-06$ & $4.70 \mathrm{E}-05$ & $6.27 \mathrm{E}-10$ & $1.04 \mathrm{E}-11$ & $5.80 \mathrm{E}-10$ & $6.56 \mathrm{E}-11$ & 2.67E-12 & $5.66 \mathrm{E}-11$ & & \\
\hline
\end{tabular}




\section{Appendix DR2 (Table DR2)}

Table DR2. Results from 1000 fold Monte Carlos simulation for time, diffusion coefficient and start and end concentrations of the diffusion profile with asymmetric error estimates of the $95 \%$ quantile. 
Table DR2

\begin{tabular}{|c|c|c|c|c|c|c|c|c|c|c|c|c|c|}
\hline element & $\begin{array}{c}\mathrm{t} \\
{[\mathrm{ka}]}\end{array}$ & \multicolumn{2}{|c|}{$\begin{array}{c}\mathrm{t} \text { (95\% Quantile) } \\
{[\mathrm{ka}]}\end{array}$} & $\begin{array}{c}\text { Diffusion } \\
\text { coefficient } \\
{\left[\mathrm{m}^{2} / \mathrm{s}\right]} \\
\end{array}$ & $\begin{array}{c}\text { Effective diffusion } \\
\text { coefficient } \\
{\left[\mathrm{m}^{2} / \mathrm{s}\right]} \\
\end{array}$ & \multicolumn{2}{|c|}{$\begin{array}{c}\mathrm{D}(95 \% \text { Quantil) } \\
{\left[\mathrm{m}^{2} / \mathrm{s}\right]}\end{array}$} & $\begin{array}{c}\text { Cstart } \\
{\left[\mathrm{cm}^{3} \mathrm{STPcm}^{-3}\right]}\end{array}$ & \multicolumn{2}{|c|}{$\begin{array}{c}\text { Cstart(95\% Quantil) } \\
{\left[\mathrm{cm}^{3} \mathrm{STPcm}^{-3}\right]}\end{array}$} & $\begin{array}{c}\text { Cend } \\
{\left[\mathrm{cm}^{3} \mathrm{STPcm}^{-3}\right]}\end{array}$ & \multicolumn{2}{|c|}{$\begin{array}{c}\text { Cend (95\% Quantil) } \\
{\left[\mathrm{cm}^{3} \mathrm{STPcm}^{-3}\right]}\end{array}$} \\
\hline${ }^{{ }^{4} \mathrm{He}}$ & 14.1 & -0.2 & 0.2 & 5.7E-08 & 4.7E-09 & $1.7 \mathrm{E}-11$ & $1.7 \mathrm{E}-11$ & $4.5 \mathrm{E}-04$ & $7.7 \mathrm{E}-06$ & \begin{tabular}{|c|}
$1.3 \mathrm{E}-05$ \\
\end{tabular} & $2.7 \mathrm{E}-05$ & $8.0 \mathrm{E}-07$ & $8.0 \mathrm{E}-07$ \\
\hline${ }^{36} \mathrm{Ar}$ & 15.1 & -0.8 & 3.4 & $1.9 \mathrm{E}-08$ & 1.6E-09 & $5.0 \mathrm{E}-12$ & $5.0 \mathrm{E}-12$ & $3.0 \mathrm{E}-08$ & $1.1 \mathrm{E}-08$ & 4.1E-09 & $1.4 \mathrm{E}-09$ & $1.3 \mathrm{E}-10$ & 2.7E-10 \\
\hline${ }^{84} \mathrm{Kr}$ & 16.9 & -0.5 & 1.1 & $1.2 \mathrm{E}-08$ & $1.0 \mathrm{E}-09$ & $5.0 \mathrm{E}-12$ & $5.0 \mathrm{E}-12$ & $1.0 \mathrm{E}-09$ & $9.0 \mathrm{E}-11$ & $5.8 \mathrm{E}-11$ & 4.4E-11 & $2.8 \mathrm{E}-12$ & $1.1 \mathrm{E}-12$ \\
\hline${ }^{132} \mathrm{Xe}$ & 15.5 & -7 & 6.8 & $9.9 \mathrm{E}-09$ & $8.2 \mathrm{E}-10$ & $1.9 \mathrm{E}-12$ & $3.9 \mathrm{E}-12$ & $6.5 \mathrm{E}-11$ & $4.0 \mathrm{E}-12$ & $9.4 \mathrm{E}-11$ & $6.9 \mathrm{E}-12$ & $6.5 \mathrm{E}-12$ & $7.1 \mathrm{E}-13$ \\
\hline$\delta^{13} \mathrm{C}$ & 15.0 & -0.5 & 0.2 & 3.6E-08 & 3.0E-09 & $1.0 \mathrm{E}-11$ & $1.0 \mathrm{E}-11$ & -7.9 & 0.5 & 0.4 & -4.0 & 0.2 & 0.2 \\
\hline
\end{tabular}




\section{Appendix DR3 (Noble gas correction)}

Since the ${ }^{3}$ He solubility is two orders of magnitude lower in the formation water than in the $\mathrm{CO}_{2}$ and the ${ }^{3} \mathrm{He}$ concentration in the formation water is several orders of magnitude lower than in the $\mathrm{CO}_{2}$, the ${ }^{3} \mathrm{He}$ concentration increase toward the gas water contact reflects the loss of $\mathrm{CO}_{2}$ by dissolution into the formation water (Fig. DR3A) (Gilfillan et al., 2009). Starting with the lowest noble gas concentration, present in the western part of the field, the concentration increase due to the loss of $\mathrm{CO}_{2}$ can be determined for ${ }^{3} \mathrm{He}$ and used to calculate the relative increase for the other noble gases (Fig. DR3B-G). This calculated increase is subtracted from the measured values to get the $\mathrm{CO}_{2}$ loss corrected value (Fig. DR3B-G, Table DR1, Equation 1) to give corrected noble gas concentrations. The equation for the $\mathrm{CO}_{2}$ loss correction is:

$$
G N G_{c}=G N G_{m}-\left[G N G_{l m c} * \frac{C_{2} /{ }^{3} H e^{\left(G N G_{l m c}\right)}}{C_{2} /{ }^{3} H e^{\left(G N G_{m}\right)}}-G N G_{l m c}\right]
$$

where GNG stands for groundwater derived noble gas, subscripts $c, m$ and $I m c$ stand for the corrected, measured and lowest measured concentration, respectively.

Fig. DR3. Noble gas concentration correction for $\mathrm{CO}_{2}$ loss by dissolution into the formation water. The ${ }^{3} \mathrm{He}$ concentration in the formation water is several magnitudes lower than in the gas phase and therefore the ${ }^{3} \mathrm{He}$ concentration increase toward the gas water contact represents the loss of $\mathrm{CO}_{2}$ to the formation water (A). The increase in ${ }^{4} \mathrm{He}$ is calculated proportional to the ${ }^{3} \mathrm{He}$ increase, starting at the lowest ${ }^{4} \mathrm{He}$ concentration (black line) (B). This is the increase in ${ }^{4} \mathrm{He}$ concentration due to $\mathrm{CO}_{2}$ dissolution (gray area) and is therefore subtracted from the measured ${ }^{4} \mathrm{He}$ concentrations. (C-G) Correction for ${ }^{20} \mathrm{Ne},{ }^{36} \mathrm{Ar},{ }^{40} \mathrm{Ar},{ }^{84} \mathrm{Kr}$ and ${ }^{132} \mathrm{Xe}$ concentrations due to solvent loss $\left(\mathrm{CO}_{2}\right.$ dissolution into the formation water) in the same way as for ${ }^{4} \mathrm{He}$ in (B). Note that ${ }^{40} \mathrm{Ar}$ is not present in excess to the relative ${ }^{3} \mathrm{He}$ increase (E). One Kr measurement lies far from the expected concentration and is excluded due to potential measuring problems (F). 

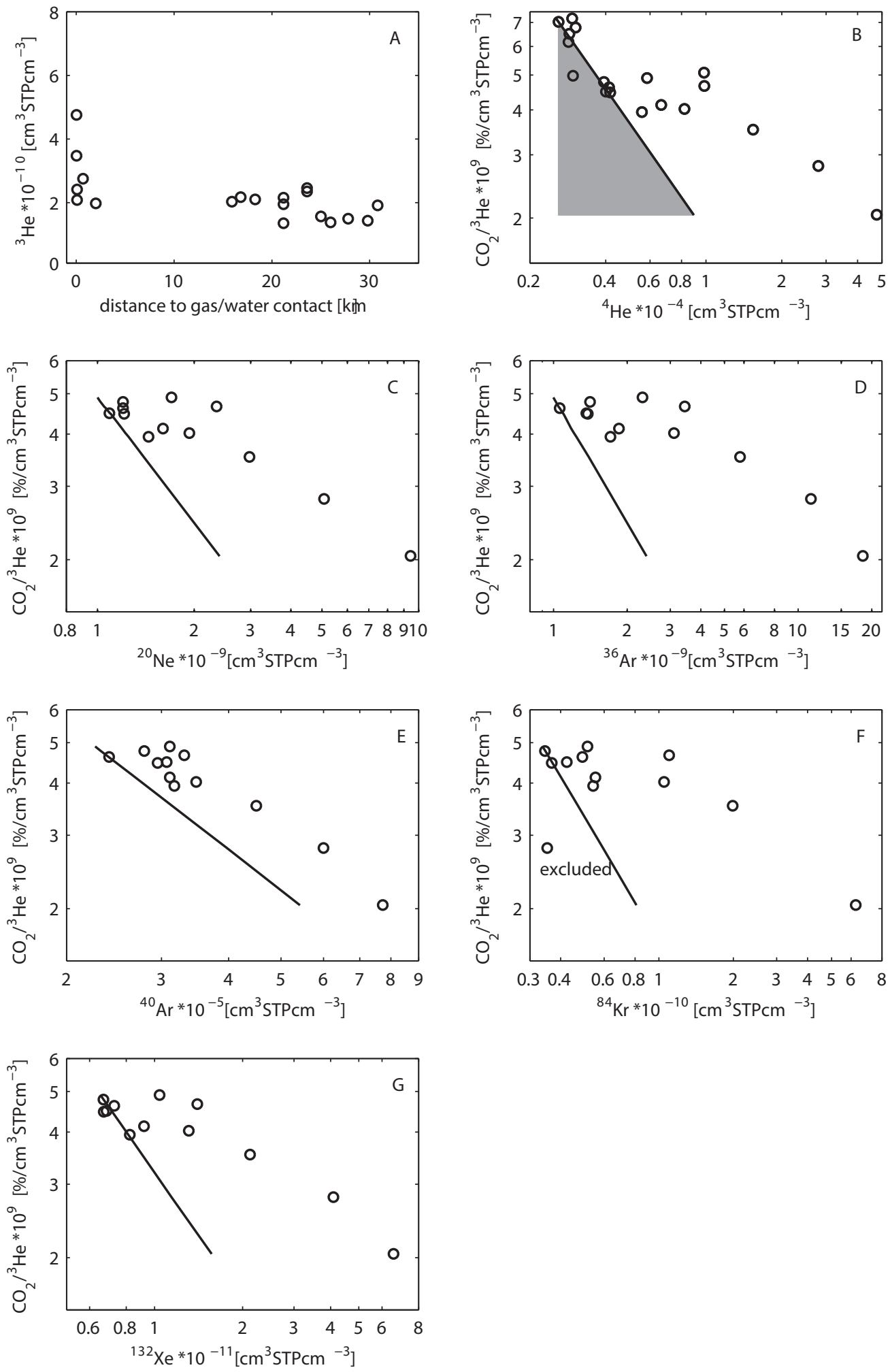


\section{Appendix DR4 (Discussion of gas/water contact)}

The western portion of the gas field is not in contact with formation water since it overlies dry impermeable basement (Cassidy, 2006), however it remains unclear how permeable the fault zone is and whether some water remains above the basement close to the fault in the south western end of the field (Sathaye et al., 2014; Akhbari and Hesse, 2017). In Figure DR4 there is one sample that does not fit the model very well and shows an enhanced noble gas concentration for its distance to the gas water contact. This sample is well $13 \mathrm{~b}$ on the south western side of the field close to the fault. This could indicate either a more permeable fault zone or water that remains above the basement in that part of the field.

Fig DR4. The corrected concentrations of noble gases and the measured stable isotopes are plotted against the distance to the gas water contact in logarithmic scale (A-H) (Fig. 2). The data point with higher noble gas concentration than expected by the model corresponds to well 13b and might indicate a more permeable fault zone or that water remains above the basement in the south western end of the field. 

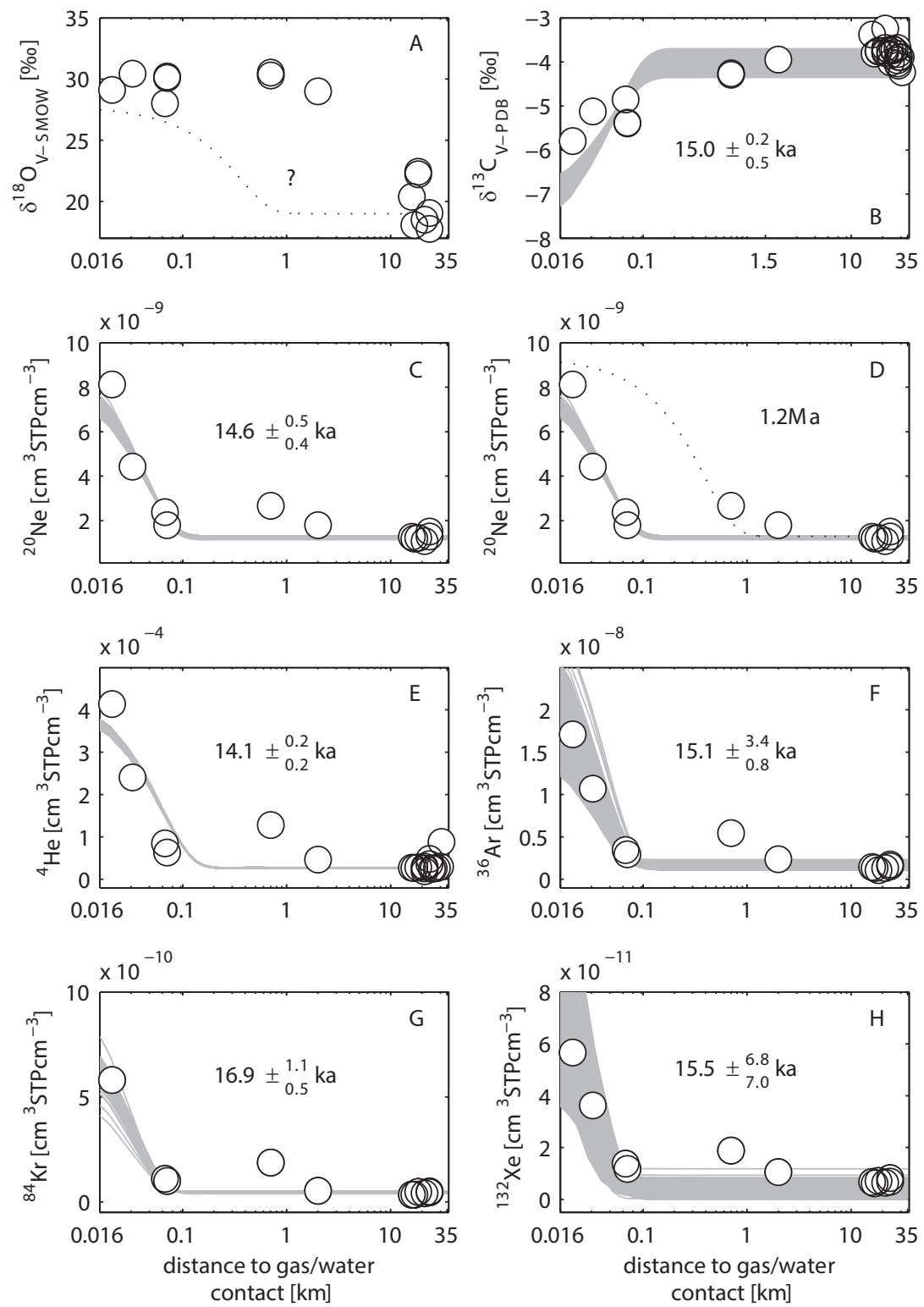


\section{References}

Akhbari, D., and Hesse, M.A., 2017, Causes of underpressure in natural CO2 reservoirs and implications for geological storage: Geology, v. 45, no. 1, p. 47-50.

Cassidy, M.M., 2006, Occurrence and Origin of Free Carbon Dioxide Gas Deposits in the Earth’s Continental Crust: UMI Dissertation Services.

Gilfillan, S.M. V, Lollar, B.S., Holland, G., Blagburn, D., Stevens, S., Schoell, M., Cassidy, M., Ding, Z., Zhou, Z., Lacrampe-Couloume, G., and Ballentine, C.J., 2009, Solubility trapping in formation water as dominant CO2 sink in natural gas fields: Nature, v. 458, no. 7238, p. 614-618, doi:

http://www.nature.com/nature/journal/v458/n7238/suppinfo/nature07852_S1.html.

Sathaye, K.J., Hesse, M.A., Cassidy, M., and Stockli, D.F., 2014, Constraints on the magnitude and rate of CO2 dissolution at Bravo Dome natural gas field: Proceedings of the National Academy of Sciences, v. 111, no. 43, p. 15332-15337. 